\title{
PENGEMBANGAN MATERI BELAJAR BERBICARA BAHASA INGGRIS UNTUK SISWA KELAS VII PROGRAM SATURDAY ENGLISH SCHOOL (SES) DI SMPIT ABU-BAKAR YOGYAKARTA
}

\author{
Dewi Yana dan Joko Priyana \\ Riau Kepulauan University, Yogyakarta State University \\ Email: alifdewi@yahoo.com, J_priyana@yahoo.com
}

\begin{abstract}
ABSTRAK
Penelitian ini bertujuan untuk: (1) mengidentifikasi kebutuhan target dan belajar siswa, (2) mengembangkan materi belajar berbicara bahasa Inggris yang tepat untuk siswa kelas VII. Jenis penelitian ini adalah penelitian dan pengembanganyang mencakup tujuh langkah kegiatan, yaitu: menganalisis kebutuhan, mengembangkan kisi-kisi pelajaran, mengembangkan draft pertama, meminta pendapat ahli, menguji coba materi, mengevaluasi dan memperbaiki materi, dan menulis draft akhir. Subjeknya adalah siswa kelas VII program SES SMPIT ABY. Data penelitian dikumpulkan melalui lembar angket dan petunjuk wawancara. Hasilnya menunjukkan bahwa: kebutuhan targetdan kebutuhan belajar siswa ABY adalah materi belajar bahasa Inggris yang terkait dengan muatan ke-Islam-an. Kebutuhan belajar siswa terkait dengan tujuan, masukan, latar, prosedur, peran guru dan peran murid. Empat unit telah dikembangkan berdasarkan kebutuhan target dan kebutuhan belajar. Nilai rata-rata setiap komponen Task untuk semua unit berada di antara 2,52< $\mathrm{E} \leq$ 3,27 dan $3,28<\mathbb{E} \leq 4,03$. Hal ini menandakan bahwa materi yang dikembangkan sudah tepat untuk siswa kelas VII program SES di SMPIT ABY.
\end{abstract}

Kata Kunci: materi belajar berbicara bahasa Inggris, Program Saturday English School (SES)

\section{THE DEVELOPMENT OF ENGLISH SPEAKING LEARNING MATERIALS FOR STUDENTS OF GRADE VII IN THE PROGRAM OF SATURDAY ENGLISH SCHOOL (SES) IN SMPIT ABU-BAKAR YOGYAKARTA}

\begin{abstract}
This research aims at: (1) identifying students' target and learning needs, and (2) developing the proper English speaking learning materials for grade VII students. This Research and Development include sevent steps of research: conducting need analysis, developing the frames of the learning materials, developing the first draft, having expert judgment, testing the materials, evaluating and improving the materials, and writing the final draft. The subject of the research is the students of grade VII in the program of Saturday English School (SES) in SMPIT ABY. The data were collected through questionnaires and interview. The results show that the students' target needs and learning needs are English learning materials related to some Islamic contents. Students' learning needs are in line with the purposes, feedbacks, settings, procedures, and the roles of the teachers and the students. Four units have been developed based on target needs and learning needs. The mean values of each Task component for all units are between $2,52<\mathbb{E} \leq 3,27$ and 3,28 $<\mathrm{E} \leq 4,03$. This signifies that the developed materials are appropriate for the students of grade VII in the program of Saturday English School (SES) in SMPIT ABY.
\end{abstract}

Keywords: english speaking learning materials, saturday english school program (ses)

\section{INTRODUCTION}

SMPIT ABY is the first integrated Islamic Junior High School in Yogyakarta.
As an integrated Islamic school, it integrates the Islamic views to its teaching and learning system. The general purpose of this school is 
to produce a balance output that is having an understanding of intelligent, emotional, and spiritual quotient. Besides Arabic, English as one of the compulsory subject also becomes the priority attention in this school. It can be seen as stated in the SMPIT ABY's mission that is increasing the Arabic and English learning program.

In reference to curriculum 2013 for Junior High School, English is allocated four hours every week and the contents are developed by the government (Kemendikbud, 2012: 15). It means that the students have limited opportunities to practice their English during the lesson and the contents provide too general contexts for SMPIT ABY's students. It challenges SMPIT ABY in improving the students' English competency in line with the specification of SMPIT as an integrated Islamic school. Therefore, SMPIT ABY has to strengthen their extracurricular activities of their English programs.

One factor that should be considered in the programs is the materials. Materials play an important role in the teaching learning process. Nunan, (1991, p. 208) argues that materials are an important element within the curriculum. Materials also facilitate the learners to acquire the target language. Richard point out that materials provide the basis for the content of the lesson, the balance of the skills taught, and the kinds of language practice the students take part in. (Richard, 2004: 252) In additions, he argues that for learners, materials should provide the mayor source of contact they have with the language apart from the teacher.

There are three roles of materials according to Richards and Rodgers (2002: 30). First, materials will focus on the communicative abilities of interpretation, expression, and negotiation. Second, materials will focus on understandable, relevant and interesting exchanges of information, rather than on the presentation of grammatical form. Third, materials will involve different kinds of texts and different kinds of media, which learners can use to develop their competence through a variety of different activities and tasks.

Despite the importance of materials, the teachers tend to use commercial materials available in the market rather than design it for their own teaching leaning process. It is not an easy work to choose the suitable and relevant materials for the students. Most of the commercial materials contain too general contexts.

A material applied in the processes of teaching and learning of SES program at SMPIT ABY should be considered as the good one. It should fulfill some good characteristics as theoretically discussed by experts. Rowntee, (1997: 92) in Richard (2002: 263) suggests a good material should have eleven characteristics as listed follows: 1) Arouse the learners' interest. 2) Remind them of earlier learning. 3) Tell them what they will be learning next. 4) Explain new learning content to them. 5) Relate these ideas to learners' previous learning. 6) Get learners to think about new content. 7) Help them get feedback on their learning. 8) Encourage them to practice. 9) Make sure they know what they are supposed to be doing. 10) Enable them to check their progress. 11) Help them to do better

Next, in line to such good characteristic of a material above, there are also sixteen characteristics points out by Tomlinson (1998: $\left.7-21^{\circ}\right)$. They are can be summarized that: firstly, materials should achieve impact. Impact is achieved when materials have a noticeable effect, on learners, that is when the learners' curiosity, interest and attention are attracted. Next, materials should help learners to feel at ease. Materials should help learners to feel at ease in a number of ways. For instance:

- Feel more comfortable with lots of white space then they do with materials in which lots of different activities.

- Are more at ease with texts and illustrations that they can relate to their own culture than they are with those which are culturally exotic (and therefore potentially alien).

- Are more relaxed with materials which are obviously trying to help them to learn than they are with materials which are always testing them.

Then, materials should help learners to develop confidence, be perceived by learners as relevant and useful, require and facilitate learners' self-investment, and expose the learners to language in authentic use. Materials should 
be drawn to linguistic features of the input, provide the learners with opportunities to use the target language to achieve communicative purposes, take into account that the positive effects of instruction are usually delayed and should take into account that learners differ in learning styles. Materials also should take into account that learners differ in affective attitudes, permit a silent period at the beginning of instruction, and maximize learning potential by encouraging intellectual, aesthetic and emotional involvement which stimulates both right and left brain activities. Last, materials should not rely too much on controlled practice, provide opportunities for outcome feedback. Then, learners must be ready to acquire the points being taught.

Tomlinson proposes ways ofapplying commonly agreed theories of language acquisition to materials development (Tomlinson 2008b in Tomlinson, 2012: 156), Theprinciples proposed include: (1) the language experience needs to be contextualized and comprehensible, (2) the learner needs to be motivated, relaxed, positive and engaged, (3) the language and discourse features available for potential acquisition need to be salient, meaningful and frequently encountered, (4) the learner needs to achieve deep and multi-dimensional processing of the language

The effective materials should reflect the language learning, match to the users' (teachers and students) belief and expectations, and adapt the materials to the students' context (Richards \& Renandya, 2002: 84). Further they add that the language characteristics of materials in relation to the current understanding of second language learning development should be contextualized, requires learner engagement in purposeful use of language, should be realistic and authentic (Richards \& Renandya 2002: 84-87). Then, classroom materials will usually seek to include an audio visual component, deal with written as well as spoken genres, foster learner autonomy, and flexible enough to cater to individual and contextual differences.

The principles of a good material as discussed by the experts above should be consider in developing the appropriate English speaking learning materials for the grade VII students of SES program at SMPIT ABY. Almost all of the principles can be used as parameters in this study. Then, knowing that SMPIT ABY integrates its teaching and learning system with Islamic views, it means the materials do not enough to cover the needs of the students.

In line to the explanation above, a study had done by Vinh (2011) from Vietnam on the first year English majors at Phuong Dong University, he found that the language input of the textbook being used in the speaking course did not fit the students' needs and judged to have some negative consequences. Therefore he developed a supplementary material to teach speaking skillfor the students. Even he did not completed his study in showing the effectiveness of the developed materials but at least he recommended that the developed materials sufficient to the vocabulary, grammar and pronunciation knowledge of the students'.

Based on such conditions explained above it can be concluded that the English learning materials being used for SMPIT ABY's are not enough to fulfill the students' needs. They have to be added or developed in line with the Islamic content. The language inputs used in the developed materials are expected can activate the students' Islamic knowledge in English.

The existence of materials that suit the students' needs and the school characteristics is very essential in the teaching learning processes. The English teaching and learning materials needed in SMPIT ABY are not only used for general purposes but also used to activate the students' knowledge of Islamic religion. Unfortunately, such materials are not available to cover the needed of English teaching and learning processes at SMPIT ABY.

Therefore this study try to answer what are the target and learning needs of English speaking learning materials for grade VII students of SES program at SMPIT Abu-Bakar Yogyakarta?; and what are the appropriate English speaking learning materials for grade VII students of SES program at SMPIT AbuBakar Yogyakarta? It is aimed at describing the target and learning needs of English speaking learning material for grade VII students of SES program at SMPIT Abu-Bakar Yogyakarta; 
and developing appropriate English speaking learning materials for grade VII students of SES program at SMPIT Abu-Bakar Yogyakarta.

This study is significance to help the teachers of SMPIT ABY to provide the appropriate English speaking learning materials based on the students' needs, and to help one who wants to explore further research on an English speaking Learning Materials.

\section{METHOD}

This research is categorized into Research and Development (R\&D) category. The model is adapted from Borg and Gall (1983: 792) and Gall, Gall and Borg (2007: 590) which is combined with some experts' model such as Masuharas', Jolly's \& Bolliho's material design (Tomlinson 1998). It is used to develop, evaluate and finish a product which can be used effectively in an educational program. This research tries to develop a new product based on the students' needs and school characteristics to minimize the problems raised. The product developed is tried out and evaluated in order to create a new product which is properly used and gives positive impacts at least for the grade VII students of SES Program at SMPIT Abu Bakar Yogyakarta.

There are seven steps of the development procedure at this research. The first step is conducting a need analysis. It is aimed at gathering the information about the target needs and the learning needs. The needs analysis is gathering through the needs analysis questionnaires.

The second step is writing the course grid. It is aimed at determining the language areas and knowledge will be learned by the learners, and it is in the form of a guideline. It is developed based on the needs analysis result in the first step.

The third step is developing the appropriate materials for the grade VII students of the SES program at SMPIT ABY. It developed based on the guideline of the course grid at the previous stage and the theory which strengthen it. It also consulted with the advisor in order to get much feedback.

The fourth step is asking the expert judgment. It is employed to estimate the criterion required in designing acceptable speaking materials before trying out the materials to the students. It is done by providing the material expert's questionnaires to the expert who is knowledgably about the materials developed and speaking theories. It also involves consultation with the expert. The developed materials which are approved by the expert then are called the second draft

. The fifth step is trying out the second draft. It is used to obtain some information whether the developed materials fit the learners' need and interest or not.Next, the second draft being evaluated. It is done by providing the try-out questionnaires and conducting the interviews with the learners.. After the feedback is obtained, the second draft then being revised to be the final draft.

The last step is writing the final draft of the materials. The final draft is written based on the tried-out questionnaires results. This final draft then will be in the form of English speaking learning materials for grade VII students of SES program at SMPIT ABY.

The design of the try out is developed based on the theories and it has been validated by the experts in teaching and learning materials. The design of try out conducted as follows. 1) First reviewing the development product by the experts of English learning materials, 2) First analyzing and revising the development product, 3) Second reviewing the development product by the experts of English learning materials, 4) Second analyzing and revising the development product, 5) Trying out the product to the grade VII students of SES Program at SMPIT $\mathrm{ABY}$, and 6) Third analyzing and revising the development product.

The subjects of the try out are chosen from the same school and grade who have similar characteristics such as their ages, dwellings, and also proficiency level . The subjects of the research are 34 students of grade VII students of Saturday English Program at SMPIT Abu Bakar Yogyakarta.

The data of this research are collected in three separated times. Firstly, the data of the learners and their needs are gathered through the first questionnaire sheets and interview guideline sheet at the early stage. In the questionnaire, the 
learners are asked to answer several questions in relation to their characteristic and their needs of learning English by choosing one or more option from several options provided.

However, they are also allowed to give other answers related to the questions. Then, to support the learners' data the instructors' opinion are obtained through interview. Secondly, the data of the material expert's opinion and suggestion to the first draft materials is obtained through the second questionnaire. Thirdly, the data of the SES program learners' opinion and their suggestions, to the tried out of the second draft materials is obtained through the third questionnaire sheets and interview guideline sheet.

In the second and the third questionnaires, a likert Scale is used to collect the data. Here, the respondents are asked to respond whether they are Strongly Agree, Agree, Disagree, or Strongly Disagree, with each statement in the questionnaires.

The instruments of this research are in the form of questionnairesheets and interviewguidelinesheet. The questionnaire sheets were provided into three separated times. The first questionnaire sheet was distributed to get the first data. It is the information about the target needs and learning needs.

Meanwhile, the second questionnaire sheet was distributed to get the second data. It is the opinions and suggestions from the material expert about the first draft. The obtained data then used to revise the first draft of developed materials. The third questionnaire sheet was distributed to get the third data. It is the learners' and the teachers' opinions and suggestions about the tried out of the second draft of the materials.

Then, the interview guideline sheets were administered into two separated times. The first interview guidelines sheet was used to gather information from the English teachers or the SES instructors. It was used to support the data obtained from the first questionnaires which were be the basis to devise the first draft of the materials. The second interview guideline sheet was used to gather information from students about their opinions related to the tried-out of the second draft of the developed materials. It was become the basis in writing the final draft of the developed materials.

There are two kinds of data being collected, namely qualitative and quantitative data. The quantitative data are obtained through the first, second, and third questionnaire sheets. Then, the qualitative data are gathered from the first and the second interview guideline sheets.

The quantitative data obtained from the first questionnaire sheet are analyzed by percentage, here, the frequency is divided by the total of the respondents, and then the result will be multiplied by $100 \%$. ( Sudijono, 2008:43).

Next,the quantitative data obtained from the second and the third questionnaire sheets are analyzed using the mean value. It is calculated by following formula as proposed by Sudijono (2008:85) below.

\begin{tabular}{|c|c|c|}
\hline \multicolumn{3}{|c|}{ 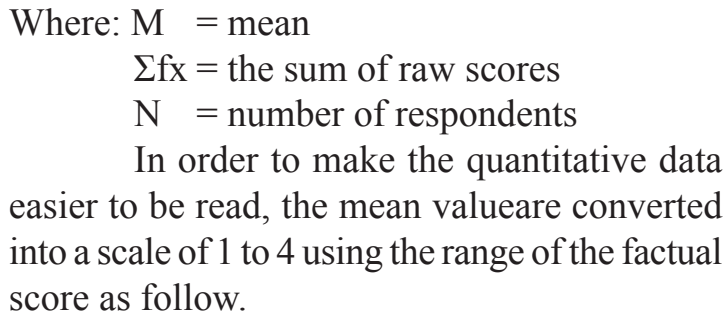 } \\
\hline Scale & Interval of Mean Values & Category \\
\hline 4 & $3.28<\ddot{X} \leq 4.03$ & Very good \\
\hline 3 & $2.52<\ddot{X} \leq 3.27$ & Good \\
\hline 2 & $1.76<\ddot{X} \leq 2.51$ & Fair \\
\hline 1 & $\ddot{X} \leq 1.75$ & Poor \\
\hline
\end{tabular}

Then, the qualitative data in the form of first and second interview records were transcribed into interview transcriptions. The first interview transcription is used to support the first quantitative data in developing the first draft of the materials. While the second interview transcriptions are used to strengthen the third quantitative data in writing the final draft of the materials.

\section{RESULTS AND DISCUSSION}

This research found that the grade VII of SES program students at SMPIT ABY needs English related to the general knowledge of Islam to be developed into English speaking 
learning materials. Therefore, a course grid was developed based on the results of the needs analysis. The contents of the course grid consist of learning objectives, unit titles, language functions, input, language focus, activities, and achievement indicators.

There were 4 units with 11 tasks for each has been developed based on the course grid. All units have the same parts.

The unit title is in the form of an expression that will be learned in the unit. It also shows the topic of the unit. The overview paragraph serves a short description of the learning objectives in the unit of developing materials. Get ready section is a warming up task. Let's Do section is spoken cycle Task. It consists of 8 tasks. Let's Check section is in the form of a task which requires students to evaluate what they have learnt from the unit. The next section, Let's Make A Reflection, is intended to measure how far the students' achievement after they learnt English in the unit. Let's Make A Summary provides important summary of the input learnt in the unit. The last section is
Vocabulary List. This section covers the glossary in the unit.

The topic of unit 1 is about the five pillars of Islam. It is related to the students' background as SMPIT students. The title is "Do you know about the five pillars of Islam?" It shows the topic and represents theexpression of asking for information. The topic of Unit 2 is about the history of Islam and Prophet Muhammad PBUH. It is related to the students' background as SMPIT students. The title is "Ienjoy learning the Islam \& Prophet Muhammad PBUH history". It represents the expression of pleasure and related to the topic will be learnt in the unit.

The topic of Unit 3 is about Khulafaurasyidin and Muslim people. It is related to the students' background as SMPIT students. The title is "Good Muslims". It represents the topics and the adjectives of describing people that will be learn in this unit. The topic of Unit 4 is about hijab. It is related to the students' background as SMPIT students. The title is "I love wearing hijab". It represents

Table 1. Try out result of unit 1

\begin{tabular}{|c|c|c|c|c|}
\hline No & Statements & $\mathbf{N}$ & MEAN & Category \\
\hline 1 & $\begin{array}{l}\text { The materials in unit } 1 \text { can help the students to improve their speaking } \\
\text { skill related to their background as SMPIT students. }\end{array}$ & 34 & 3.38 & $\begin{array}{l}\text { Very } \\
\text { good }\end{array}$ \\
\hline 2 & $\begin{array}{l}\text { The materials in unit } 1 \text { can help the students activating their general } \\
\text { knowledge of Islam in English. }\end{array}$ & 34 & 3.26 & Good \\
\hline 3 & $\begin{array}{l}\text { The tittle of unit } 1 \text { can help the students predicting the materials will be } \\
\text { given. }\end{array}$ & 34 & 3.21 & Good \\
\hline 4 & $\begin{array}{l}\text { The overview paragraph of unit } 1 \text { (the part after the tittle) helps the } \\
\text { students knowing the learning goal. }\end{array}$ & 34 & 3.15 & Good \\
\hline 5 & The Input given is enough (it fits to the students' needs). & 34 & 3.06 & Good \\
\hline 6 & The language use in the text is comprehensible. & 34 & 3.21 & Good \\
\hline 7 & The dialogues given are easy to be learnt and understandable. & 34 & 3.12 & Good \\
\hline 8 & The topics given related to the students' general knowledge of Islam. & 34 & 3.18 & Good \\
\hline 9 & The pictures given are appropriate to the topics used in unit 1 & 34 & 3.15 & Good \\
\hline 10 & $\begin{array}{l}\text { The explanations of English expressions taught are easy to be } \\
\text { understood. }\end{array}$ & 34 & 3.18 & Good \\
\hline 11 & $\begin{array}{l}\text { The exercises in unit } 1 \text { are systematically given from the simple one to } \\
\text { the complex one. }\end{array}$ & 34 & 3.12 & Good \\
\hline 13 & $\begin{array}{l}\text { 'Vocabulary list' in unit } 1 \text { helps the students to understand the text } \\
\text { given. }\end{array}$ & 34 & 3.18 & Good \\
\hline 14 & $\begin{array}{l}\text { 'My reflection' in unit } 1 \text { helps students to measure their achievement } \\
\text { toward the material given. }\end{array}$ & 34 & 3.18 & Good \\
\hline 15 & The materials appearance is interesting. & 34 & 3.15 & Good \\
\hline
\end{tabular}


likes expression

There were some evaluation notes given from the expert. They were related to the content, language, presentation, and to the graphic of the first draft of developed materials. The notes then were used to revise the first draft to the second draft.

The appropriateness of the second draft were measured based on the tried-out.The result of try-out questionnaire of unit 1 in the form of descriptive qualitative data can be seen in Table 1.

Based on Table 1 above, it can be seen that most of the statements are in good category (with the mean values in range of $2.52<\mathrm{E} \leq 3.27)$, while the rest are in very good category (with the mean values in range of 3.28 $<\mathrm{E} \leq 4.03)$. Therefore, it can be concluded that generally the materials of unit 1 were appropriate to the students.

The result of the try-out questionnaire of unit 2 in the form of descriptive qualitative data can be seen in Table 2 .
Based on Table 2 above, it can be seen that all of the statements are in good category (with the mean values in range of $2.52<$ $(\mathrm{E} \leq 3.27)$. Therefore, it can be concluded that generally the materials of unit 2 were appropriated to the students.

The result of the try-out questionnaire of Unit 3 in the form of descriptive qualitative data can be seen in Table 3 .

Based on Table 3 above, it can be seen that all of the statements are in good category with the mean values in range of $2.78<\mathrm{EE} \leq 3.25$ and in the interval of $2.52<\mathrm{E} \leq 3.27$. They mean that the students agreed to unit 3 . Therefore, it can be concluded that generally the materials of unit 3 were appropriated to the students.

The result of the try-out questionnaire of unit 4 in the form of descriptive qualitative data can be seen in Table 4 .

Based on Table 4above, it can be seen that most of the statements are in good category (with the mean values in range of $2.52<\mathrm{E} \leq$ 3.27), while three of them is in the very good

Table 2. Try out result of unit 2

\begin{tabular}{|c|c|c|c|c|}
\hline No & Statements & $\mathbf{N}$ & MEAN & Category \\
\hline 1 & $\begin{array}{l}\text { The materials in unit } 2 \text { can help the students to improve their } \\
\text { speaking skill related to their background as SMPIT students. }\end{array}$ & 33 & 3.12 & Good \\
\hline 2 & $\begin{array}{l}\text { The materials in unit } 2 \text { can help the students activating their general } \\
\text { knowledge of Islam in English. }\end{array}$ & 33 & 3.27 & Good \\
\hline 3 & $\begin{array}{l}\text { The tittle of unit } 2 \text { can help the students predicting the materials will } \\
\text { be given. }\end{array}$ & 33 & 3.09 & Good \\
\hline 4 & $\begin{array}{l}\text { The overview paragraph of unit } 2 \text { (the part after the tittle) helps the } \\
\text { students knowing the learning goal. }\end{array}$ & 33 & 2.97 & Good \\
\hline 5 & The Input given is enough (it fits to the students' needs). & 33 & 2.97 & Good \\
\hline 6 & The language used in the text is comprehensible. & 33 & 3.00 & Good \\
\hline 7 & The dialogues given are easy to be learnt and understandable. & 33 & 2.97 & Good \\
\hline 8 & The topics given related to the students' general knowledge of Islam. & 33 & 3.15 & Good \\
\hline 9 & The pictures given are appropriate to the topics used in unit 2 & 33 & 3.12 & Good \\
\hline 10 & $\begin{array}{l}\text { The explanation of English expressions taught is easy to be } \\
\text { understood. }\end{array}$ & 33 & 3.18 & Good \\
\hline 11 & $\begin{array}{l}\text { The exercises in unit } 2 \text { are systematically given from the simple one } \\
\text { to the complex one. }\end{array}$ & 33 & 3.09 & Good \\
\hline 12 & The instructions of each Task are clear and easy to be understood. & 33 & 3.06 & Good \\
\hline 13 & $\begin{array}{l}\text { 'Vocabulary list' in unit } 2 \text { helps the students to understand the text } \\
\text { given. }\end{array}$ & 33 & 3.06 & Good \\
\hline 14 & $\begin{array}{l}\text { 'My reflection' in unit } 2 \text { helps students to measure their achievement } \\
\text { toward the material given. }\end{array}$ & 33 & 3.03 & Good \\
\hline 15 & The materials appearance is interesting. & 33 & 3.12 & Good \\
\hline
\end{tabular}


Table 3. Try out result of Unit 3

\begin{tabular}{|c|c|c|c|c|}
\hline No & Statements & $\mathbf{N}$ & MEAN & Category \\
\hline 1 & $\begin{array}{l}\text { The materials in unit } 3 \text { can help the students to improve their } \\
\text { speaking skill related to their background as SMPIT students. }\end{array}$ & 34 & 3.16 & Good \\
\hline 2 & $\begin{array}{l}\text { The materials in unit } 3 \text { can help the students activating their general } \\
\text { knowledge of Islam in English. }\end{array}$ & 34 & 3.25 & Good \\
\hline 3 & $\begin{array}{l}\text { The tittle of unit } 3 \text { can help the students predicting the materials will } \\
\text { be given. }\end{array}$ & 34 & 2.94 & Good \\
\hline 4 & $\begin{array}{l}\text { The overview paragraph of unit } 3 \text { (the part after the tittle) helps the } \\
\text { students knowing the learning goal. }\end{array}$ & & 3.09 & \\
\hline 5 & The Input given is enough (it fits to the students' needs). & 34 & 3.22 & Good \\
\hline 6 & The language used in the text is comprehensible. & 34 & 2.88 & Good \\
\hline 7 & The dialogues given are easy to be learnt and understandable. & 34 & 2.94 & Good \\
\hline 8 & The topics given related to the students' general knowledge of Islam. & 34 & 3.13 & Good \\
\hline 9 & The pictures given are appropriate to the topics used in unit 3 & 34 & 3.00 & Good \\
\hline 10 & $\begin{array}{l}\text { The explanations of English expressions taught are easy to be } \\
\text { understood. }\end{array}$ & 34 & 2.94 & Good \\
\hline 11 & $\begin{array}{l}\text { The exercises in unit } 3 \text { are systematically given from the simple one } \\
\text { to the complex one. }\end{array}$ & 34 & 3.00 & Good \\
\hline 12 & The instructions of each Task are clear and easy to be understood. & 34 & 2.91 & Good \\
\hline 13 & $\begin{array}{l}\text { 'Vocabulary list' in unit } 3 \text { helps the students to understand the text } \\
\text { given. }\end{array}$ & 34 & 3.06 & Good \\
\hline 14 & $\begin{array}{l}\text { 'My reflection' in unit } 3 \text { helps students to measure their achievement } \\
\text { toward the material given. }\end{array}$ & 34 & 3.00 & Good \\
\hline 15 & The materials appearance is interesting. & 34 & 2.78 & Good \\
\hline
\end{tabular}

category (with the mean values in range of 3.28 $<\mathbb{E} \leq 4.03)$. Therefore, it can be concluded that generally the materials of unit 4 were appropriated to the students.

Theresult also shows that the six of task components of the four units were appropriate to the students. The first component is concerning to task goals, the task goals were considered appropriate to the grade VII of SES program at SMPIT ABY when the goals helps the students to improve their speaking skill in relation to their background as SMPIT students, it is activating their general knowledge of Islam in English. For instance in unit 1, the students learn about the five pillars of Islam and asking for and giving opinions/information expressions.

Generally in Indonesian, the students already understand about the five pillars of Islam, but they need helps to activate that knowledge in English. The try out results were obtained that almost all of the task goals of the units in the materials developed were appropriate. It proved with the interval mean value of $3.28<\mathrm{EE} \leq 4.03$ and $2.52<\mathrm{EE} \leq 3.27$. It can be conclude that the materials developed were helping the students to activate their general knowledge of Islam in English.

The students learn the language of something they already knew. It is in line with Tomlinson (2008b in Tomlinson, 2012:156) opinion that the language experience needs to be contextualized and comprehensible. The developed materials were also relevant to the students' backgrounds. It is supported by (Richards \& Renandya, 2002:84) that the effectives materials should reflect the language learning, match to the users' (teachers and students) belief and expectations, and adapt the materials to the students' context.

The second component is related to task inputs. The task inputs were considered appropriate to the grade VII students of SES program at SMPIT ABY when the inputs were comprehensible; fit the students' needs; and relevant to the goals. Based on the try-out results, they were obtained that the task inputs in the materials developed were appropriate to the students. Those task inputs were in the form of 
Table 4. Try out result of unit 4

\begin{tabular}{|c|c|c|c|c|}
\hline No & Statements & $\mathbf{N}$ & MEAN & Category \\
\hline 1 & $\begin{array}{l}\text { The materials in unit } 4 \text { can help the students to improve their } \\
\text { speaking skill related to their background as SMPIT students. }\end{array}$ & 34 & 3.36 & $\begin{array}{l}\text { Very } \\
\text { good }\end{array}$ \\
\hline 2 & $\begin{array}{l}\text { The materials in unit } 4 \text { can help the students activating their general } \\
\text { knowledge of Islam in English. }\end{array}$ & 34 & 3.33 & Very \\
\hline 3 & $\begin{array}{l}\text { The tittle of unit } 4 \text { can help the students predicting the materials will } \\
\text { be given. }\end{array}$ & 34 & 3.00 & Good \\
\hline 4 & $\begin{array}{l}\text { The overview paragraph of unit } 4 \text { (the part after the tittle) helps the } \\
\text { students knowing the learning goal. }\end{array}$ & 34 & 3.09 & Good \\
\hline 5 & The Input given is enough (it fits to the students' needs). & 34 & 3.18 & Good \\
\hline 6 & The language use in the text is comprehensible. & 34 & 2.88 & Good \\
\hline 7 & The dialogues given are easy to be learnt and understandable. & 34 & 2.88 & Good \\
\hline 8 & The topics given related to the students' general knowledge of Islam. & 34 & 3.27 & Good \\
\hline 9 & The pictures given are appropriate to the topics used in unit 4 & 34 & 3.27 & Good \\
\hline 10 & $\begin{array}{l}\text { The explanations of English expressions taught are easy to be } \\
\text { understood. }\end{array}$ & 34 & 3.00 & Good \\
\hline 11 & $\begin{array}{l}\text { The exercises in unit } 4 \text { are systematically given from the simple one } \\
\text { to the complex one. }\end{array}$ & 34 & 3.06 & Good \\
\hline 12 & The instructions of each Task are clear and easy to be understood. & 34 & 3.09 & Good \\
\hline 13 & $\begin{array}{l}\text { 'Vocabulary list' in unit } 4 \text { helps the students to understand the text } \\
\text { given. }\end{array}$ & 34 & 3.21 & Good \\
\hline 14 & 'My reflection' in unit 4 helps students to measure their achievement & 34 & 3.12 & Good \\
\hline 15 & The materials appearance is interesting. & 34 & 3.33 & $\begin{array}{l}\text { Very } \\
\text { Good }\end{array}$ \\
\hline
\end{tabular}

monologues, dialogues, conversation, pictures, charts, and spoken text. There were also some authentic materials such as video, verses of the Qur'an, and Ramadan time-table. The students were used those inputs to richer their language competences. It is in line with Richard (2002: 252) argument that materials inputs provide kinds of language practice the students take part in. Moreover, it also related Tomlinson (1998:2) who said that inputs can be used to "increase the learners' knowledge and/or experience of the language".

The third component is related to procedures. The task procedures were considered appropriate to the grade VII students of SES program at SMPIT ABY when the students can work the activities and they were motivated to speak in English. The try-out analysis results found that the task procedures in the developed materials were appropriate to the students. The procedures were dominated with speaking activities. While other activitieslistening, pronunciations, vocabularies and language functions activities were supporting the speaking activities. Those varieties of activities can develop the students' competence. It is in line with one of the three materials roles according to Richards and Rodgers (2002:30); materials involved different kinds of texts, media, a variety of different activities and tasks can be used to develop students' competence. Generally, it can be concluded the students were motivated and stimulated to speak in English through those varieties of activities.

The next component is related to task settings. The task settings are considered appropriate to the grade VII students of SES program at SMPIT ABY when the students can enjoy doing the Task and finish it comfortably. The try out results found that the students were comfort to do the tasks individually, in partners and in groups. Doing the tasks in pairs or small groups is the setting they enjoyed most. It relevant to Nair \& Alwee (2012) research that there some benefits of doing Task in groups. They are providing interesting and enjoyable learning; promote interaction among teammates; and as an effective learning mechanism. Therefore, It can be concluded that the setting used in the developed materials were success to make 
students complete the Tasks in the developed materials enjoyably and comfortably

The last components are related to teacher's and students' roles. The roles were considered appropriate to the grade VII students of SES program at SMPIT ABY when the students can do the tasks actively, and when the teacher can helps and support the students completely their tasks. Based on the try-out results, they were obtained that the teacher's and students' roles in the materials developed were appropriate. The students' role was the active participants, while the teacher's roles were as an observer, a feedback provider, a prompter, and a tutor. It can be concluded that the teacher's role were supported students' role to speak in English. Their roles were can not be separated each other. It is relevant to Harmer (2001) opinion that teacher's role is relevant to get students speak fluently.

\section{CONCLUSION}

This research is conducted to answer three main questions: what are the target needs of the grade VII students of SES program at SMPIT ABY?; What are the learning needs of the grade VII students of SES program at SMPIT ABY?; What is the appropriate English Speaking Learning material for the grade VII students of SES program at SMPIT Abu-Bakar Yogyakarta?

he first and the second questions are answered through the needs analysis questionnaires. The needs analysis found that the target needs of the grade VII students of SES program at SMPIT ABY are the English speaking learning materials which are related to Islamic contents. They wanted to use it for their futures such as to communicate to friends from abroad or tourist and to take the interview for getting study abroad. Moreover, the students need the English speaking learning materials to improve their speaking in the Novice-High level, to enrich their vocabulary, to train them pronouncing the words appropriately, and to speak in English fluently.

Then, the learning needs of the grade VII students of SES program at SMPIT ABY were related to the six task components proposed by Nunan (2004). The first component is goal.
Related to goal, the students need the English speaking learning materials to express their prior knowledge of Islam with appropriate grammar and vocabulary. The second one is input. Regarding to input, the students need the English speaking learning materials in the form of short monologue, dialogue, list of vocabularies related to the topics to be discussed in the units and the examples of the expression that will be used in the units.

Moreover, they also need the topic of the input to be related to the five pillars of Islam, the history of Islam, the history of Prophet Muhammad PBUH, the history of Prophet's companions, and Islamic contemporary. In addition, the students need the length of input between 200-250 words. The third component is procedure. Pertaining to procedure, the students need the English speaking learning materials which cover the activities of discussing a particular topic, questions and answers, roleplay, and games. The next component is setting. Regarding to setting, the students need the English speaking learning materials which can be done in pairs, and in small groups. Then, the fifth and six components are students' and teacher's role. The students need the English speaking learning materials which can be involved them to be active in the speaking learning processes and they need the teacher to play a relevant role with their activities.

Four units with 11 tasks were developed. All units have the same task numbers. And each unit also has the same parts; introductions, main activities, and reinforcement. The introduction has a unit title and an overview paragraph. The unit title is in the form of a topic and expression that will be learnt in the unit. The overview paragraph provides general information about the learning objectives. The main activities have some tasks which are divided into two sections namely Get Ready and Lets' Do. Get ready section is a warming up task. Let's Do section is spoken cycle Task. The reinforcement is divided into four sections; they are Let's Check, Let's Make a Reflection, Let's Make a Summary and Vocabulary List.

The first draft materials were evaluated to the expert of material development and English teaching. The results of the expert's 
evaluation were used to revise the first draft materials to be the second draft materials. Next, to know whether the second draft materials were appropriate or not, the tried-out was done to the students.

The results of the tried-out found that the second draft materials were appropriate. It can be proved that all the task components of the four units of the second draft materials have the interval mean value of $3.28<\mathrm{E} \mathrm{d}$ " 4.03 and $2.52<\mathrm{E}$ d" 3.27. Then, the appropriate materials to the grade VII students of SES program at SMPIT ABY have the following characteristics.

Related to goal, the materials should improve the students' speaking skill in relation to students' background as SMPIT students; it is related to Islamic contents. Related to input, it should comprehensible, fit the students' needs, and relevant to the goals. Related to procedure, it should being able to be done well and motivated the students to speak in English.Related to setting, it should can be done individually, or in pairs, and or in small groups.Regarding to the learners' and teacher's roles, it should give opportunities for students to be active participants. The teacher can play relevant roles to support the students completely their tasks well as an observer, a feedback provider, a prompter, and a tutor.

Therefore, it can be concluded that the appropriate English speaking learning materials for the grade VII students of SES program at SMPIT ABY was the tasks that can be used to improve the students' speaking skill in relation to their background as SMPIT students. The tasks inputs should comprehensible, fit the students' needs, and relevant to the goals. The tasks procedures can be done well and motivated the students to speak in English. The tasks setting can be done by individually, in pairs, and in small groups. The students can do the tasks actively, and the teacher can helps and support the students completely their tasks.

\section{Ucapan Terima Kasih}

Artikel ini disusun berdasarkan tesis yang telah diujikan dan direvisi. Oleh karena itu, saya mengucapkan terima kasih kepada pembimbing Joko Priyana, Ph.D. dan dewan penguji tesis yang telah memberi masukkan dan saran terhadap tesis saya. Dengan bantuan tersebut artikel hasil penelitian ini dapat diwujudkan.

\section{REFERENCES}

Borg, W\& Gall. 1983. An Introduction Educational Research: Fourth Edition. Longman: New York \& London.

Gall, M.D, Gall, J.P. \& Borg, W.R. 2007. Educational Research: An Introduction: EightEdition. New York: Pearson Education, Inc

Harmer, J. 2001. The Practice Of English Language Teaching: Third Edition Completely Revised And Updated. Cambridge: Longman.

Kemendikbud . 2012. Instrument D Penilaian Buku Panduan Pendidik Tahun 2012. Badan penelitian dan pengembangan pusat kurikulum dan perbukuan.

Nunan, D. 1991. Language Teaching Methodology: A Textbook For Teachers. New York: Prentice Hall. .2004. Task-based language teaching. Cambridge: Cambridge University Press.

Richards. J.C. 2002.Curriculum Development in Language Teaching. Cambridge: Cambridge University Press.

Richards, J.C., \& Renandya, W.A. (Ed). 2002. Methodology In Language Teaching: An Anthology of Current Practice. Cambridge: Cambridge University Press

Sudijono, A. 2008. Pengantar Statistik Pendidikan. Jakarta: PT Raja Grafindo Persada

Tomlinson, B.(Ed). 1998. Materials Development for Language Teaching. Cambridge: Cambridge University Press. . 2012. Materials development for language learning and teaching. StateOf-The-Art Article Lang.Teach.@ Cambridge University Journal Press, 45.2, 143-179

Vinh, N.T.H. 2011. Developing Supplementary Material To Teach Speaking Skill for First Year English Majors At Phuong Dong University. Hanoi: Vietnam National University. (electronic published) 